\title{
THE EFFECT OF PROCEDURAL JUSTICE ON ORGANIZATIONAL CITIZENSHIP BEHAVIOR (OCB) WITH TRUST AS THE INTERVENING VARIABLE
}

\author{
Elok Ainur Latif*1, Mutia Pamikatsih ${ }^{2}$ \\ Universitas Nahdlatul Ulama Al Ghazali, Indonesia*12 \\ elokainurlatif@gmail.com¹ ${ }^{*}$ mutiacilacap4560@gmail.com²
}

Abstract: This study describes the effect of perceptions of procedural justice that employees feel on the organization and supervisor. Different sources that exist in perceptions of procedural justice will affect different OCB. This influence can be proven through the mechanism of social exchange relations that occur between organizational procedural justice and OCB which is mediated by trust. This research was conducted to determine the role of the target similarity model by examining the relationship of multifoci procedural justice, social exchange, and employee OCB together. The research sample involved nurses who worked at RSI (Islamic Hospital) Fatima Cilacap. Data collection was carried out using survey methods and questionnaires. Data analysis was performed using simple regression analysis through mediation. The results of this study found that the role of procedural justice in an organization is very important. Employees who have a perception of procedural justice will feel highly valued in their role as part of the organization so that the OCB shown to the organization tends to be high. The higher the level of perceptions of procedural justice felt by employees, the motivation of these employees to always show a higher OCB towards the organization and supervisor will also increase.

Keywords: Procedural Justice, Trust, Organizational Citizenship Behavior

\section{INTRODUCTION}

Organizational justice interprets employees' perceptions of the fair treatment they get in their work and its effect on other work variables (Nwibere, 2014). One type of organizational justice is procedural justice which is known to have a positive relationship with OCB/organizational citizenship behavior (Lehmann-Willenbrock et al., 2013).

The development of research on procedural justice in organizations provides research results that show that the high level of OCB from employees is not only caused by the direct influence of procedural justice, but other attitudinal factors also contribute to increasing OCB, for example, trust. The results of other studies also show that trust is considered capable of being one of the variables that mediate the relationship between procedural justice and OCB (Lehmann-Willenbrock et al., 2013; Yuen Onn et al., 2018). Employees with high perceptions of procedural justice can find it easier to trust the organization, so they volunteer to help work outside their main job (Lavelle et al., 2014). Employees with a high level of trust in the organization will find it easier to show OCB to the organization (Lehmann-Willenbrock et al., 2013).

Research that focuses on procedural justice with OCB has always experienced continuous development. Several other studies only focus on the role of specific organizational justice in general and its impact on employee OCB (Ibrahim \& Perez, 2014; Nwibere, 2014). However, Lavelle et al. (2014) found that justice does not only explain employees' perceptions of justice within the organization, but other reasons cause employees to have fair or unfair perceptions of the organization in the results of recent research on perceptions of organizational justice. An explanation of this reason can be put forward through a multifoci approach and the target similarity model. Both of 
these approaches can explain the origin of the source of justice that is felt by employees together, both from the organization and the supervisor. The difference in sources of justice within the organization is very relevant to the social exchange that occurs between employees and the organization (Lavelle et al., 2014). The results obtained will indicate that the procedural justice felt by employees may not only come from the organization but can also come from their supervisor.

This study aims to determine the role of the target similarity model, namely by examining the relationship of multifoci procedural justice, social exchange, and employee OCB together. The use of a multifoci approach and the target of similarity models in examining the role of organizational justice allows this study to become one of the latest studies with the theme of research on perceptions of organizational justice. The reason is that the use of these two approaches in a study related to the perception of organizational justice is still relatively new so that not many researchers have researched with the same approach theme.

The literature review and hypothesis formulation in this research are :

Procedural Justice

This is the employee's perception of the formal procedures that are applied in an organization for decision making, either by direct superiors or by the organization, whether it is done fairly or unfairly (Leventhal, 1980). According to Leventhal (1980), six rules must be used as a reference in assessing procedural justice in an organization, namely consistency, minimization of bias, accurate, fixable, representative, and ethical information.

A fair assessment of decisionmaking procedures is important because it will affect employee attitudes and behavior towards the results of decisions made by the organization (Singh \& Srivastava, 2016).

Trust this is related to the level of individual trust in other individuals who have competence where these other individuals can take ethical, fair, and predictable actions (Nyhan \& Marlowe, 1997). Nyhan \& Marlowe (1997) define trust as consisting of four dimensions, namely humanistic, affiliation, achievement-oriented, and selfactualization.

With the growth of trust in the organization and supervisors, it will also have a positive impact on improving performance such as OCB both for the organization and for the supervisor (Lehmann-Willenbrock et al., 2013).

OCB/Organizational Citizenship Behavior is an optional behavior by employees and there is no written reward system when employees do it. However, this non-mandatory behavior is generally able to improve organizational performance functions (Newton \& Jeffery, 2018). Williams \& Anderson (1991) suggested two dimensions in the OCB structure, namely OCB for Organizations (OCBO) and OCB for Supervisor (OCBS).

If an employee feels procedural justice in the organization and his supervisor is fair, then the employee will have high trust in both of them, so he will tend to show high OCB to the organization and its supervisors (Akram et al., 2018).

The role of justice in the organization gives a tendency to form conditions for interdependent relationships between employees and the organization. This interdependent relationship can be explained through social exchange theory (Blau PM, 1964). High social exchange relationships can motivate employees to show an abound attitude towards the organization to behave by certain consequences. One of the reasons for this depends on the employee's perceived justice towards the organization or supervisor. One of the consequences of this relationship is 
that it will allow employees to improve performance and show OCB (van Dijke et al., 2010).

Cropanzano et al. (2017) stated that in the results of their research it was found that when employees have a perception of injustice in social exchange relationships, the employee will show negative reactions in the form of negative emotions, attitudes, and behavior towards the organization. Employees who have a low level of procedural justice perceptions will tend to engage in counter-productive work behavior (Lehmann-Willenbrock et al., 2013). Based on the understanding of the explanation above, it can be concluded that through this social exchange theory, the reciprocal relationship between organizations and employees regarding rewards, sacrifices, and benefits that will influence each other can be described (Shalini \& Masterson, 2011).

\section{Multifoci Theory and Target Similarity Model}

The use of a multifoci approach aims to assess perceptions of justice that originate from different sources, namely perceptions of organizational justice and supervisors simultaneously. Employees may have the perception that their organization is being fair, but on the other hand, their supervisors are not being fair and vice versa. Meanwhile, the similarity model target supports a multifoci approach and can explain the reactions of employees' perceptions of justice and social exchanges that occur. This reaction will then have a direct impact on the same attitudes and behaviors as well (Lavelle et al., 2014). Employees who have perceptions of procedural justice from different sources tend to have different effects on the targets they are working on (Lavelle et al., 2014).

Referring to several theories put forward by experts and the results of the above research findings, the hypotheses proposed in this study are as follows:

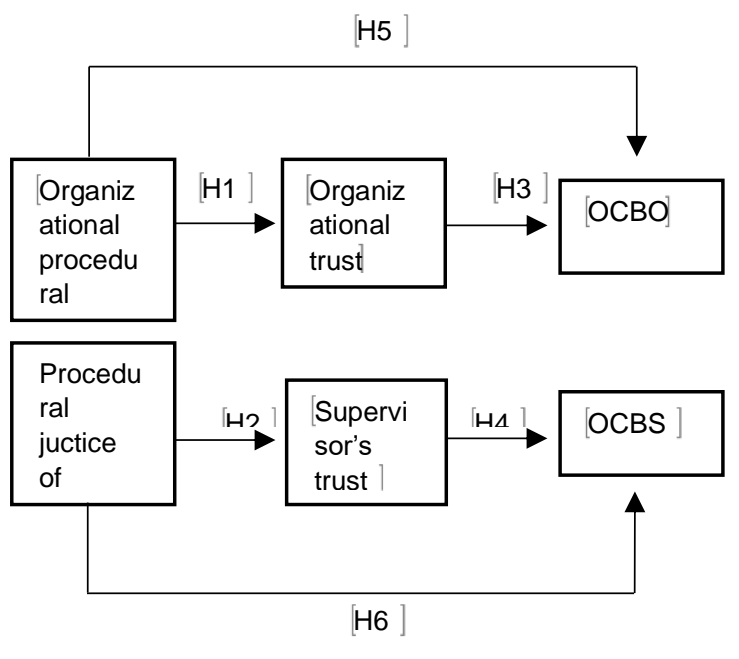

Figure 1. Research Model

Source: Processed data (2020)

$\mathrm{H} 1$ : Organizational procedural justice has a positive effect on organizational trust

H2: The supervisor's procedural justice has a positive effect on the supervisor's trust

H3: Organizational trust has a positive effect on OCBO

$\mathrm{H} 4$ : Supervisor's trust has a positive effect on OCBS

H5: Organizational trust mediates the association between organizational procedural justice and OCBO

H6: Supervisor's trust mediates the association between supervisor's procedural justice and OCBS

\section{METHODS}

Based on the nature and dimension of time, this research is research with a quantitative approach with cross-sections. The questionnaire is used as a data collection tool. The sample in the study consisted of 87 nurses who worked at the Islamic Hospital (RSI) Fatimah Cilacap. Sampling was carried out by purposive sampling method in which samples were selected based on predetermined characteristics. A total of 87 nurses who were the samples in this study were part of several groups of certain rooms or classes in the hospital. The criteria for selecting the sample included the 
sample having been through a service period of more than 1 year and had indeed been recommended by the intended organization due to a decrease in performance and perceptions of social relations between employees and organizations that were not good in the department. The method of analysis used in this research was regression analysis with mediation using the causal step method.

RESULTS AND DISCUSSION Validity and Reliability Test

Table 1. Validity and Reliability Test

\begin{tabular}{|c|c|c|c|}
\hline Variable & r-count & r-table & Ket \\
\hline $\mathrm{X} 1.1$ & 0,688 & 0,210 & Valid \\
\hline $\mathrm{X} 1.2$ & 0,709 & 0,210 & Valid \\
\hline $\mathrm{X} 1.3$ & 0,663 & 0,210 & Valid \\
\hline X1.4 & 0,707 & 0,210 & Valid \\
\hline X1.5 & 0,521 & 0,210 & Valid \\
\hline $\mathrm{X} 1.6$ & 0,623 & 0,210 & Valid \\
\hline $\mathrm{JX} 1$ & 0,732 & & Reliable \\
\hline $\mathrm{X} 2.1$ & 0,647 & 0,210 & Valid \\
\hline X2.2 & 0,596 & 0,210 & Valid \\
\hline$X 2.3$ & 0,580 & 0,210 & Valid \\
\hline$X 2.4$ & 0,591 & 0,210 & Valid \\
\hline X2.5 & 0,591 & 0,210 & Valid \\
\hline X2.6 & 0,670 & 0,210 & Valid \\
\hline JX2 & 0,667 & & Reliable \\
\hline X3.1 & 0.624 & 0,210 & Valid \\
\hline X3.2 & 0,805 & 0,210 & Valid \\
\hline X3.3 & 0,790 & 0,210 & Valid \\
\hline X3.4 & 0,766 & 0,210 & Valid \\
\hline $\mathrm{JX3}$ & 0,737 & & Reliable \\
\hline X4.1 & 0,708 & 0,210 & Valid \\
\hline$X 4.2$ & 0,717 & 0,210 & Valid \\
\hline X4.3 & 0,810 & 0,210 & Valid \\
\hline$X 4.4$ & 0,752 & 0,210 & Valid \\
\hline X4.5 & 0,705 & 0,210 & Valid \\
\hline X4.6 & 0,769 & 0,210 & Valid \\
\hline$X 4.7$ & 0,772 & 0,210 & Valid \\
\hline$X 4.8$ & 0.471 & 0,210 & Valid \\
\hline JX4 & 0.863 & & Reliable \\
\hline Y1.1 & 0,531 & 0,210 & Valid \\
\hline Y1.2 & 0,699 & 0,210 & Valid \\
\hline Y1.3 & 0,710 & 0,210 & Valid \\
\hline Y1.4 & 0,745 & 0,210 & Valid \\
\hline Y1.5 & 0,693 & 0,210 & Valid \\
\hline Y1.6 & 0,712 & & \\
\hline JY1 & 0,770 & & Reliable \\
\hline Y2.1 & 0.606 & 0,210 & Valid \\
\hline Y2.2 & 0.730 & 0,210 & Valid \\
\hline Y2.3 & 0,824 & 0,210 & Valid \\
\hline Y2.4 & 0,817 & 0,210 & Valid \\
\hline Y2.5 & 0,738 & 0,210 & Valid \\
\hline JY2 & 0,800 & & Reliable \\
\hline
\end{tabular}


Based on the result obtained from the measurement conducted through the SPSS program, it is known that as a whole, the validity value of the statement on the research variable has a greater correlation than the r-table value of 0.210 . This indicates that the questionnaire used is valid. Furthermore, for the reliability test value, the results were greater than 0.60 which means that all statements in the form of a questionnaire are reliable to be used as research instruments.

\section{Hypothesis test}

After the data from this study passes which proved through the classical assumption test stage and has met the stipulated requirements, the next step that should be done is hypothesis testing. The table below presents a summary of the regression test results. The values shown in the table are the regression coefficient $(B)$, t-count, and significance value for each relationship between variables where the result of t-table is 2,372 .

Table 2. The Results of Regression Analysis with t table of 2.372

\begin{tabular}{cccccc}
\hline No & Hypothesis & B Value & t-count & Sig. & Conclusion \\
\hline 1 & H1 & 0,417 & 4,353 & 0,000 & Accepted \\
2 & H2 & 0,507 & 5,743 & 0,214 & Accepted \\
3 & H3 & 0,341 & 4,390 & 0,000 & Accepted \\
4 & H4 & 0,211 & 1,251 & 0,214 & Rejected \\
5 & H5 & 0,509 & 4.161 & 0,000 & Accepted \\
6 & H6 & 0,168 & 3,088 & 0,003 & Rejected \\
\hline
\end{tabular}

Source: Processed data (2020)

According to the table above, we can describe the results are:

The Effect of Procedural Justice of Organization on Organizational Trust

In this study, the effect of procedural justice of an organization has a positive influence on organizational trust. This influence is in line with research conducted by Lehmann-Willenbrock et al. (2013) that the procedural justice of an organization has a positive relationship with trust in organizations. Another study conducted by Zeinabadi \& Salehi (2011) and van Dijke et al. (2010) also indicates that procedural justice of an organization is found to be one of the most important antecedents, both for organizational trust and trust for supervisors. Thus, the first hypothesis states that organizational procedural justice has a positive effect on organizational trust and it is acceptable.

\section{The Effect of Procedural Justice of Supervisor on Supervisor's Trust}

Based on the results of this study, it can be seen that the procedural justice of the supervisor influences the supervisor's trust. From the results of the calculation of the t-test, the value of the $t$ value is 5.743 with a significance value of 0.000 or less than the alpha value $(\alpha=0.05)$. This shows that partially the variable procedural justice of the supervisor has a significant effect on the supervisor's trust. Thus, the second hypothesis which asserts that the procedural justice of the supervisor has a positive effect on the supervisor's trust is acceptable.

The influence of a supervisor's procedural justice on supervisor's trust is in line with research conducted by Singh \& Srivastava (2016) that the procedural justice of a supervisor is one of the most important antecedents for supervisor's trust. Another study conducted by Lehmann-Willenbrock et al. (2013) also concluded that 
employees who have fair perceptions of supervisors will also tend to have a trusting attitude towards supervisors in the organization.

\section{The Effect of Trust from the Organization and Supervisors on OCB}

Based on the results of calculations with regression analysis on the relationship between organizational trust and OCBS (supervisor), it is known that the $t$-count of the organizational trust variable is $4,390>$ t-table 2,372 with a significance level of 0,000 or less than its alpha value $(\alpha=$ $0.05)$. Regarding the results, it can be seen that partially organizational trust has a significant effect on OCBO. Thus, the third hypothesis which states that organizational trust has a positive effect on OCBO is acceptable.

Furthermore, the value of the $t$ count of supervisor's confidence is $1.251<\mathrm{t}$ table 2.372 with a significance value of 0.214 . From the results of these calculations, or less than the alpha value $(\alpha=0.05)$. From these results, it can be seen that part, the supervisor's trust does not have a significant effect on OCBS. Thus, the fourth hypothesis which states that the supervisor's trust has a positive effect on OCBS is rejected. This is in line with research conducted by Elamin \& Tlaiss (2015) which states that a supervisor's trust does not affect OCBS. This is because employees who have a perception of trust in their supervisor do not directly affect OCBS. Employees who have little confidence in their supervisor, still show good behavior towards their supervisor because they feel that they have to behave well towards their direct supervisor (Akram et al., 2018).

\section{Organizational Trust to Mediate the Relationship between Organizational Procedural Justice of Organization and OCBO}

To discover the effect of organizational procedural justice on
OCBO with organizational trust as a mediation variable, regression analysis with mediation is used through the causal step method (Suliyanto, 2011). Based on the analysis calculation, the following results are obtained.

In the initial regression calculation of the organizational procedural justice variable on organizational trust, the result is 0.417 with a significance of 0.000 . Furthermore, the regression equation for the variable organizational trust in OCBO shows a result of 0.341 with a significance level of 0.000 . Furthermore, after entering the mediating of organizational trust of a variable in the relationship of organizational justice on OCBO, the result is 0.243 while remaining significant at 0.014 .

Based on the above calculations, it can be seen that the direct effect of the organizational procedural justice variable on OCBO is 0.417 , while the indirect effect is 0.243 . This points out that organizational trust has a partially mediate influence on the relationship between organizational procedural justice and OCBO so that the fifth hypothesis is accepted.

The mediating effect of organizational trust on the relationship between organizational procedural justice and OCBO shows that high organizational trust in employees/nurses, will increase the perceptions of organizational procedural justice and ultimately have an impact on the increase of OCBO.

Organizational trust can provide the effect of mediation between procedural justice and OCBO. The mediating effect of the organizational trust variable on employees/nurses at Fatima Islamic Hospital in Cilacap can increase OCBO. The results of this study support the research results of Cropanzano et al. (2017) which show that trust is a relational construct to understand social exchange within organizations. This is also in agreement with the existence of social exchange theory (Blau PM, 1964) which argues 
that social exchange theory is a reciprocal interaction relationship within an organization that is mutually beneficial to both parties, namely through the relationship between trust and OCB.

The results of this study also support the results of the research of Zeinabadi \& Salehi (2011) which argues that trust can be the most essential antecedent for OCB. This implies that if employees feel procedural justice in their organization is carried out fairly, then these employees will find it easier to believe in the organization. Furthermore, if the employees already have high trust in the organization, then they will tend to show high OCB for the organization.

\section{The Trust of Supervisor to Mediate the Relationship between Procedural Justice of Supervisor and OCBS}

The analysis used on the relationship between these variables uses regression analysis with mediation through the causal step method (Suliyanto, 2011). Based on the analysis calculation, the following results are obtained.

In the initial regression calculation of the supervisor's procedural justice variable on organizational trust, the result is 0.507 with a significance of 0.000. Furthermore, the regression equation for the variable supervisor's trust in OCBS shows a result of 0.211 with a significance level of 0.214 . Furthermore, after entering the variable of mediating trust in the supervisor on the relationship of procedural justice of organization towards OCBS, the result is 0.472 while remaining significant at 0.003 .

Based on the above calculations, it can be known that the value of the direct effect of the supervisor's procedural justice variable on OCBS is 0.507 , while the indirect effect is 0.472 . This shows that the supervisor's trust has no significant effect on the relationship between the supervisor's procedural justice and OCBS, thus the sixth hypothesis is rejected. The mediating effect of supervisor's trust on the relationship between supervisor's procedural justice and OCBS shows that with a high of supervisor's trust in employees/nurses, it will not always increase the perceptions of supervisor's procedural justice and ultimately have an impact on the decrease of OCBS.

Dealing with the results of this study, it points out that the supervisor's trust does not mediate the relationship between the supervisor's procedural justice and OCBS. The results of this study are in line with the results of research conducted by Akram et al. (2018) which argues that supervisor's trust does not mediate the relationship between perceptions of justice towards OCBS / OCB supervisors. This is in line with the results of the hypothesis of procedural justice of supervisor which does not have a significant positive relationship to the supervisor's trust. Thus, the OCBS produced by employees (nurses) does not have a close relationship between the supervisor's procedural justice and the supervisor's trust. After the researcher asked directly some of the respondents that were used in this study, it points out that several real factors can influence in this regard. Employees will still show good OCBS even though they have a little justice and trust in their supervisors. This is due to there is a sense of employee attachment to the organization, the consideration of costs, and the fear of getting poor performance appraisals when they do not show good behavior towards their supervisor.

\section{CONCLUSION}

The results of the fourth and sixth hypotheses in this study were rejected. This was unique due to many other studies that have stated that there was a relationship between supervisor's procedural justice, supervisor's trust, and OCBS. The results of the study were not always in line with the hypothesis proposed, it indicated that 
each OCBS that showed by employees to their supervisors, did not always have a relationship with the supervisor's perceived justice. Based on further observations of several respondents regarding this problem, several respondents said that there was a sense of employee attachment to the organization, the consideration of costs, and fear of poor performance appraisals when they did not show good behavior towards their supervisor. This may need to be reviewed in the following research regarding the relationship between supervisor's procedural justice, supervisor's trust, and OCBS by adding other variables, respondent differences, or measurement differences.

\section{REFERENCES}

Akram, A., Kamran, M., Iqbal, M. S., Habibah, U., \& Atif Ishaq, M. (2018). The impact of supervisory justice and perceived Supervisor support on organizational citizenship behavior and commitment to supervisor: the mediating role of trust. Cogent Business and Management, 5(1), 1-17.

Blau PM. (1964). Exchange and Power in Social Life (J. Wiley \& Sons (eds.)). Transaction Publisher.

Cropanzano, R., Anthony, E. L., Daniels, S. R., \& Hall, A. V. (2017). Social exchange theory: A critical review with theoretical remedies. Academy of Management Annals, 11(1), 479-516.

Elamin, A. M., \& Tlaiss, H. A. (2015). Exploring the relationship between organizational citizenship behavior and organizational justice in the Islamic Saudi Arabian context. Employee Relations, 37(1), 2-29.

Ibrahim, M. E., \& Perez, A. O. (2014). Effects of Organizational Justice, Employee Satisfaction, and Genderon Employees' Commitment: Evidence from the UAE. International Journal of Business and Management, 9(2).
Lavelle, J. J., Rupp, D. E., Jennifer, M., \& Meghan, A. T. (2014). Multifoci Justice and Target Similarity: Emerging Research and Extensions (Oxford University (ed.)). Oxford University.

Lehmann-Willenbrock, N., Grohmann, A., \& Kauffeld, S. (2013). Promoting multifoci citizenship behavior: Time-lagged effects of procedural justice, trust, and commitment. Applied Psychology, 62(3), 454-485.

Leventhal, G. S. (1980). What Should be Done with Equity Theory? New Approaches to the Study of Fairness in Social Relationships. Differences.

Manajemen, J., Vol, B., \& Issn, B. T. (2014). Almana: Jurnal Manajemen dan Bisnis Vol. - No. /Bulan Tahun ISSN 2579-4892 print/ ISSN 2655-8327 online. 1-9.

Newton, \& Jeffery, L. A. (2018). Organizational Citizenship Behavior and Engagement "You Gotta Keep 'Em Separated. The Oxford Handbook of Organizational Citizenship Behavior: Oxford University Press.

Nwibere. (2014). Organizational Justice as a Determinant of Organizational Citizenship Behavior in The Nigerian work Environment: a Study of Selected Universities in The Niger Delta Region. International Journal of Business, 9, 191-205.

Nyhan, R. C., \& Marlowe, H. A. (1997). Development and psychometric properties of the organizational trust inventory. Evaluation Review, 21(5), 614-635.

Shalini, K., \& Masterson, S. S. (2011). Who and What are Fair Matters: A Multifoci Social Exchange Model of Creativity. Journal of Organizational Behavior, 32, 86106.

Singh, U., \& Srivastava, K. B. L. (2016). Organizational trust and organizational citizenship behaviour. Global Business 
Review, 17(3), 594-609.

Suliyanto. (2011). Ekonometrika

Terapan: Teori dan Aplikasi dengan SPSS (1st ed.). ANDI.

van Dijke, M., De Cremer, D., \& Mayer, D. M. (2010). The Role of Authority Power in Explaining Procedural Fairness Effects. Journal of Applied Psychology, 95(3), 488502.

Williams, L. J., \& Anderson, S. E. (1991). Job Satisfaction and Organizational Commitment as Predictors of Organizational Citizenship and In-Role Behaviors. Journal of Management, 1991(1), 601-617.

Yuen Onn, C., Nordin bin Yunus, J., Yusof, $\mathrm{H}$. binti, Moorthy, K., \& Ai $\mathrm{Na}$, S. (2018). The mediating effect of trust on the dimensionality of organisational justice and organisational citizenship behaviour amongst teachers in Malaysia. Educational Psychology, 38(8), 1010-1031.

Zeinabadi, H., \& Salehi, K. (2011). Role of procedural justice, trust, job satisfaction, and organizational commitment in organizational citizenship behavior (OCB) of teachers: Proposing a modified social exchange model. Procedia Social and Behavioral Sciences, 29(Iceepsy), 1472-1481. 